\title{
Fine Structural Changes in the Trigeminal Motor Nucleus Following Neurotomy of the Third Division of the Trigeminal Nerve*
}

\author{
Kikuko Iмамото
}

\section{Received January 19, 1973}

Summary. The fine structural changes during retrograde degeneration were studied in the trigeminal motor nucleus from $17 \mathrm{hrs}$ to 95 days following neurotomy of the 3rd division of the trigeminal nerve in the rat.

The typical Nissl bodies composed of a parallel array of long granular endoplasmic reticulum presented derangement and fragmentation. Concomitantly an accumulation of polysomes became eminent in the perinuclear area adjacent to the nuclear indentation and the peripheral portion of the perikaryon. In the neuron with advanced degeneration, dilatation of cisterns of the granular endoplasmic reticulum and gradual change of polysomes to single free ribosomes were demonstrated. However, the motor neurons concerned gave few necrotic images, suggesting the recovery from the affection. Concernig the highly dark and shrunken neurons frequently observed in the affected side of the motor nucleus some possibilities were discussed.

The lamellar cisterns of the Golgi apparatus were replaced by well-developed Golgi vesicles, coated vesicles and dense bodies. Neurofilaments and neurotubules moderately increased in number and irregularly dispersed without forming unique bundles. The mitochodria often showed indistinct cristae and a decrease in electron density of the matrix.

In the neuropil some axon terminals supposed to be axon collaterals from the trigeminal mesencephalic neurons showed moderate abnormalities characterized by the high density of the axoplasm, glycogen accumulation and the occasional appearance of neurofilaments. Directly after neurotomy the microglial cells markedly proliferated as satellites, which migrated around the neurons separating synaptic endings from the synaptic area with finger-like processes. The necrotic neuron was completely enclosed and digested within a hypertrophied microglial cytoplasm. Astrocytal processes around the nerve cells and vascular walls accumulated glycogen particles shortly after operation. An astrocytal perikaryon showed hypertrophy with gliofilamentous proliferation but an increase in the number of astrocytes was obscure.

The fine structural changes during axonal reaction have been described in the last decade by several investigators (PAnnese, 1963; TAKAno, 1964; BArron et al., 1967; Kirkpatrick, 1968; Torvik and Skjörten, 1971a; Price and Porter, 1972; Torvik, 1972). However, there are conflicting findings which are considered to depend on the differences in animal species, cell types, severity of damage, etc. Although most of the ultrastructural changes seem to be concerned with internal cellular reorganization preparing for regeneration of the affected axon (LIEBERMAN, 1971), it was thought necessary to make some experiments in different nerve cells, which had not been examined by other investigators.

In the present study the motor nucleus of the trigeminal nerve in the rat was

*This study was supported by a grant (No. 90425) from the Japan Ministry of Education. 
studied with an electron microscope following section of the 3rd division of the trigeminal nerve, and the results were compared with the histochemical data (IмAмото, 1972a) and ultrastructural changes in the trigeminal mesencephalic nucleus (IмAмото, 1972b). Discussion was also made with reference to the relationship between fine structural changes and metabolic ones.

\section{Material and Method}

Male albino rats weighing from 150 to $200 \mathrm{~g}$ were used in this experiment. Neurotomy of the third division of the trigeminal nerve was performed and about $1 \mathrm{~mm}$ of its distal stump was removed below the foramen ovale on the left side of the rat. Survival times varied from $17 \mathrm{hrs}$ to 95 days after operation. These animals were sacrificed by perfusion fixation with cold $4 \%$ glutaraldeylate $(0.1 \mathrm{M}$ cacodylate buffer pH 7.3) or modified Karnovsky's fixative (0.1 M phosphate buffer pH 7.3) for 15 minutes under ether anethesia. The objective area was trimmed and post-fixed for $1 \mathrm{hr}$ with chilled $1 \%$ or $2 \%$ osmium tetroxide (veronal buffer or phosphate buffer $\mathrm{pH}$ 7.3). After routine procedures of ethanol dehydration and propylene oxide immersion the blocks were embedded in Epon 812. Semi-thin sections of about $1 \mu$ were stained with $1 \%$ toluidine blue solution and sometimes with PAS reaction. The ultra-thin sections were subjected to double metallic staining with uranyl acetate and lead citrate and examined under a HU-11B type electron microscope.
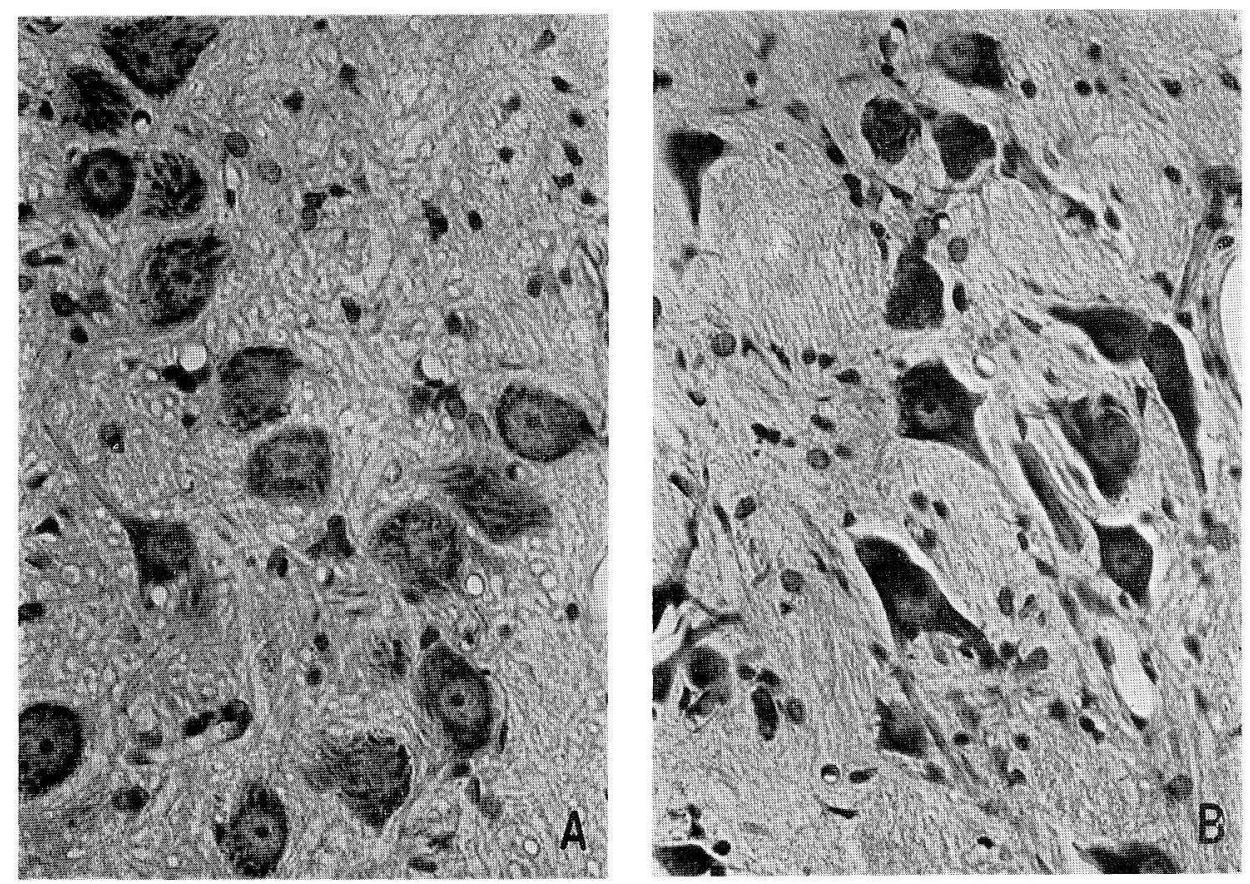

Fig. 1. The trigeminal motor neurons stained with gallocyanin after 4 day survival. The control neurons (A) show typical tigroid bodies, while the affected neurons (B) show indistinct appearance of the Nissl bodies. They become wholly hyperchromic and shrunken with mild nuclear eccentricity. 


\section{Results}

\section{Normal or control motor nuclei}

The trigeminal motor nucleus is composed of many large multipolar neurons and a few medium-sized neurons, having typical tigroid bodies (Fig. 1A). The large masses of the tigroid bodies or the Nissl bodies exhibit a parallel array of long granular endoplasmic reticulum with rosette-like polysomes between the cisterns (Fig. 3). The cell nucleus located in the center of the neuron, is pale and of large spherical type with a prominent nucleolus. The Golgi apparatus composed of several lamellar cisterns and a few Golgi vesicles are well-developed throughout the perikaryon. Other cell organelles such as mitochondria with clear cristae, small lysosomes, a small amount of neurofilaments and neurotubules are observed in light cytoplasmic matrix. Since there are many synaptic contacts which almost completely cover the surface of the neurons and dendrites, glial attachment to the surface of the neuron is very rare as compared with the mesencephalic neurons (Imamoto and Shimizu, 1970). The afferent nerve fibers into the motor nucleus are mixed with S-type and F-type terminals containing several mitochondria and make many axo-dendritic synapses and axo-somatic ones. The fine structures stated above seem to reflect the strong activities of succinic dehydrogenase (SDH), lactic dehydrogenase (LDH) and aldorase (ALD) in the histochemical data in the perikarya and neuropil of the motor nucleus
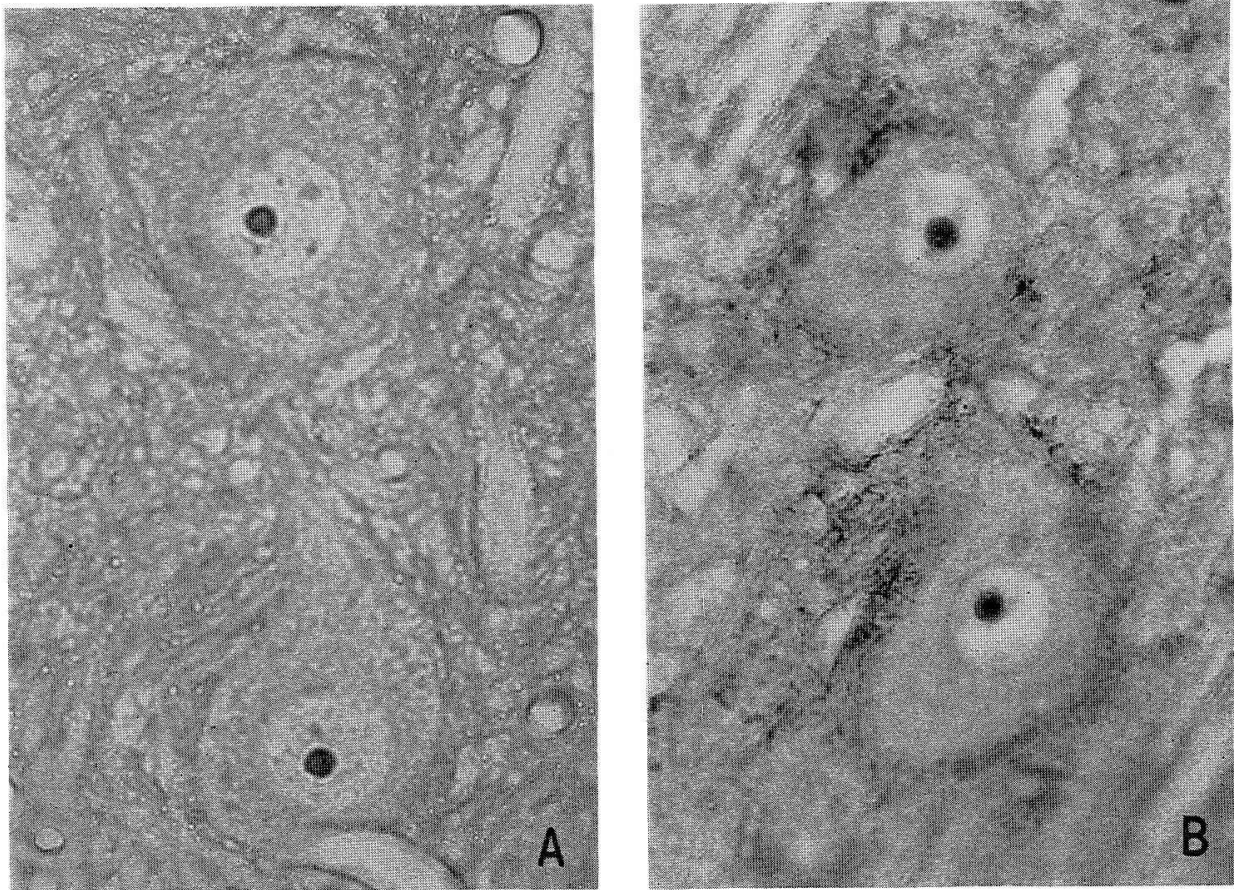

Fig. 2. PAS reaction with dimedone treatment of Epon embedded section, after 10 day survival. Perineuronal area on the affected side $(\mathbf{B})$ is remarkably occupied with increased glycogen in comparison with the control side $(\mathbf{A}) . \quad \times 500$ 
(Iмамото 1972a). Periodic acid Shiff (PAS) reaction is negligible as shown in Figure $2 \mathrm{~A}$ and as indicated in the previous experiments both in the neurons and neuropil.

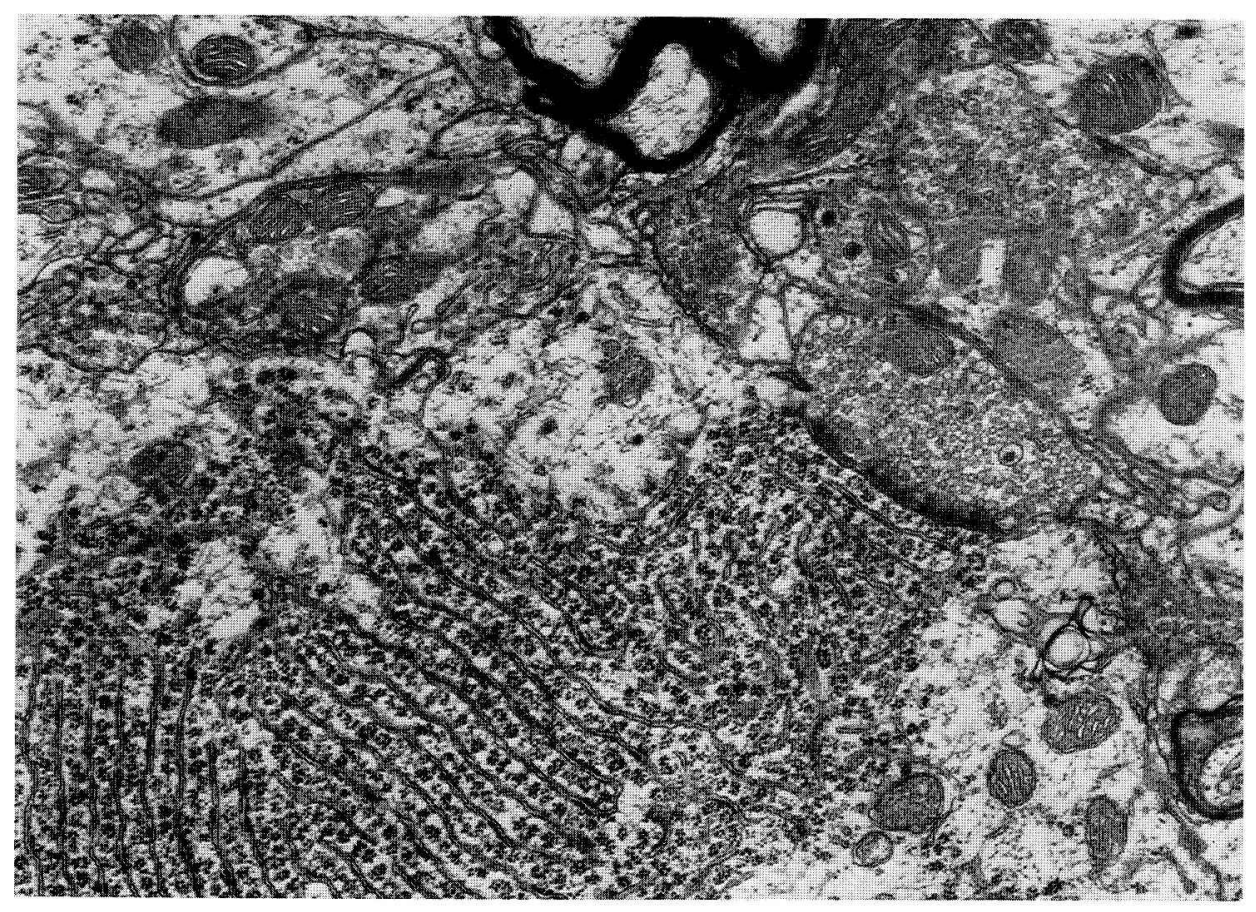

Fig. 3. Intact Nissl body in the trigeminal motor neuron. Observe the parallel array of the long granular ER and rosette-like polysomes dispersing among the cisterns. $\times 18,000$

\section{Observations in the perikaryon of the affected motor neuron}

In general the retrograde changes in the trigeminal motor neurons were rather mild through the survival periods, as compared with the case of the mesencephalic neurons (IMAMOTO, 1972b). The appearance of hyperchromic neurons was the initial change and subsequently the diffuse dispersion of the typical Nissl masses followed. The homogeneous hyperchromic stainability with gallocyanin probably depends on an increase in polysomes and free ribosomes instead of the parallel array of the long granular ER (Fig. 4, 6). Even after 10 days, however, the hyperchromic changes were not substituted for chromatolysis with cell swelling and nuclear eccentricity (Fig. 1B). That was different from the cases of the trigeminal mesencephalic neurons (atrophic central chromatolysis) and the anterior horn cells (swelling central chromatolysis).

Nuclear dislocation and infolding were also mild in the motor neurons, but the infolded area was often filled with numerous polysomes and free ribosomes. With the advancement of changes in the Nissl substances, most of the motor neurons showed higher electron opacity in the cytoplasmic matrix (Fig. 5, 6, 7). Only a few neurons, which seemed to be undergoing necrotic degeneration, showed severe shrinkage during the first 4 days and then lost the Nissl substances. The necrotic neuron became filled with dense amorphous materials (Fig. 18). 


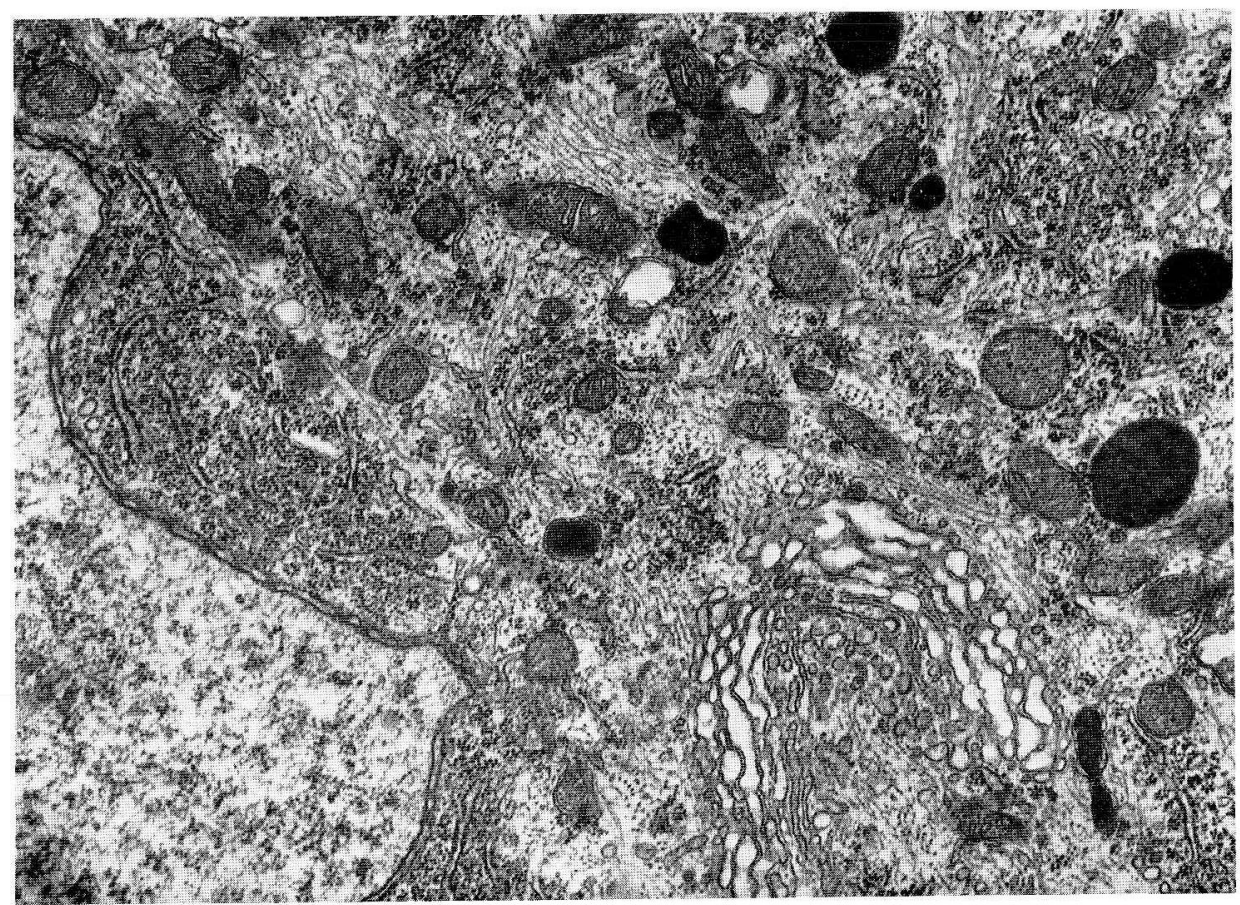

Fig. 4. Perinuclear area of the affected neuron after 10 day survival. Note the disarrangement of the granular ER, increased polysomes, free ribosomes, neurofilaments and a well-developed Golgi apparatus. $\times 19,000$

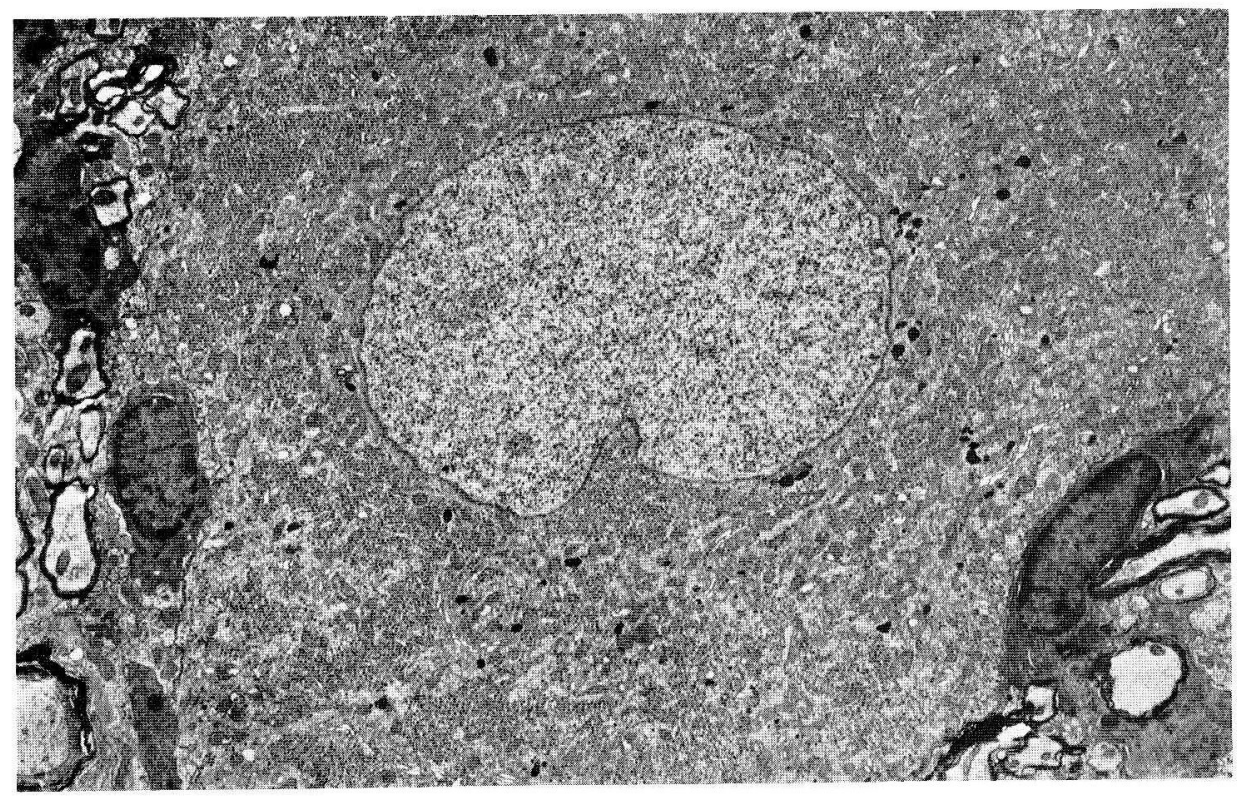

Fig. 5. The trigeminal motor neuron surrounded by more than 4 microglial cells after 10 day survival. Dispersion of the Nissl substances and mild nuclear infolding are observed. $\times 3,200$ 
The Golgi apparatus was progressively activated and accompanied by structural changes. Namely the unique lamellar cisterns of the Golgi apparatus were replaced by many Golgi vesicles, coated vesicles, dense bodies and multivesicular bodies (Fig. $4,6,15)$. Around the Golgi area the density of the matrix became increased. These structural changes seem to be concerned with a decrease of thiamine pyrophosphatase activity (unique in the Golgi apparatus) in the axotomized facial neurons of the rats (Oka, Uefuji, Mori and Imamoto; in preparation).

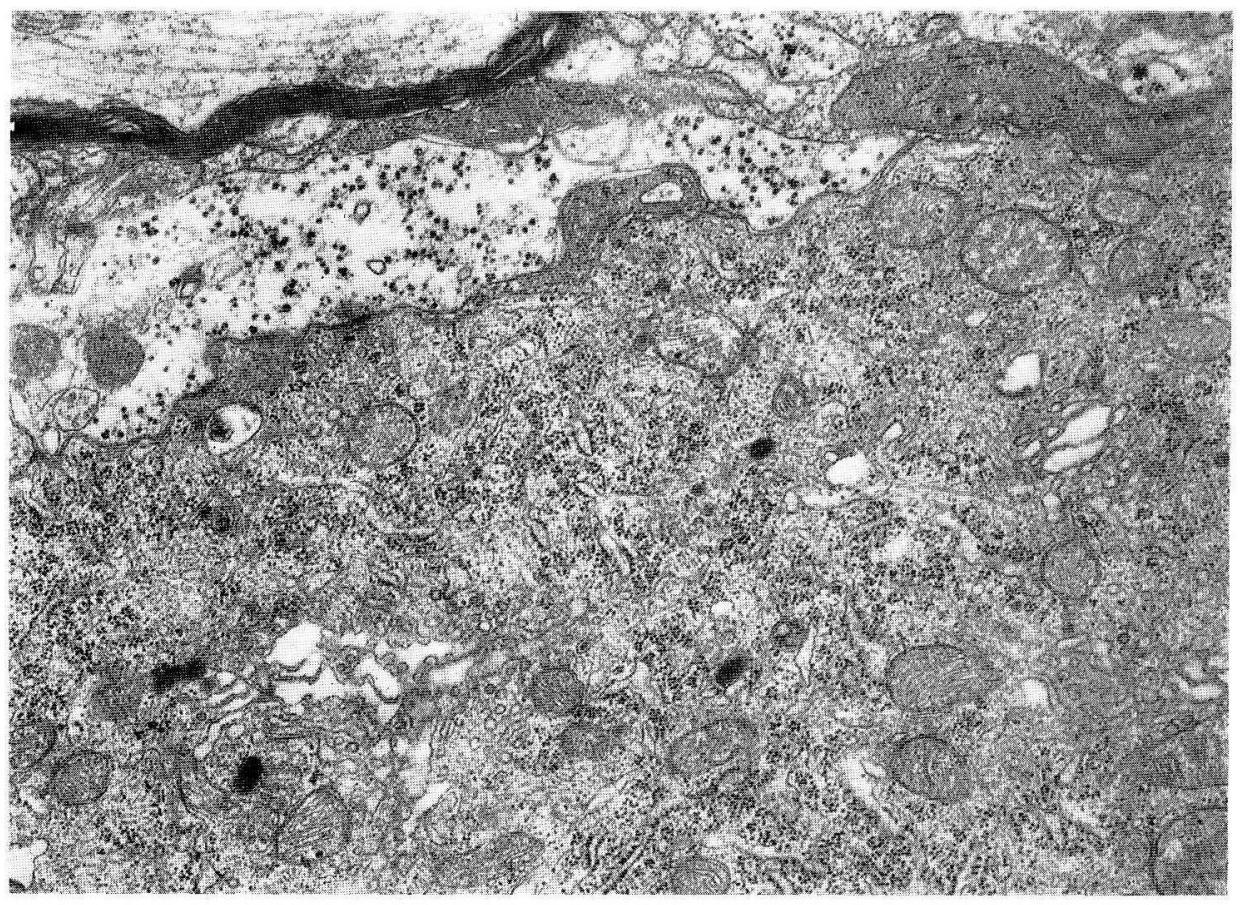

Fig. 6. Peripheral cytoplasm of the affected neuron after 10 day survival. The Nissl substances in the dense cytoplasmic matrix are represented by ribosome-like particles, the cisterns being shorted and extended. Note glycogen particles in the astrocytal end feet and finger-like microglial processes along the neuronal surface. $\times 18,000$

On the other hand marked neurofilamentous aggregation reported in the mesencephalic neurons was not observed in the motor neurons (Iмамото, 1972b). The newly synthesized neurofilaments and neurotubules were distributed at random without the formation of bundles (Fig. 4).

During retrograde degeneration especially in the cases of 7, 10 and 21 days survivals markedly dark neurons were frequently recognized (Fig. 8, 9, 10). These neurons showed irregular contours of perikaryon and cell nucleus and enormous condensation of cell organelles, probably due to strong dehydration. In the dense nucleus chromatin and nucleolus were barely preserved, while in the dense perikaryon many light mitochondria with indistinct outline and few cristae, the Golgi apparatus, the extending cisterns of the granular endoplasmic reticulum and numerous single ribosomes larger than usual were identified fairly clearly (Fig. 9, 10). 
The pattern of the Nissl substances was highly specific, and polysome formation was never recognized in the dark shrunken neurons. The unit membrane structures in the nuclear envelope, the granular ER, mitochondria, the Golgi apparatus and even the cell membrane became indistinct and often disappeared, while abnormal lamellated membranous structures appeared (Fig. 9). Especially, the outer nuclear membrane became loose and the space of $200-250 \AA$ between inner and outer nuclear membranes increased to $2,000 \AA$ in several portions except for the nuclear pore area (Fig. 9). However, the surface of such dark shrunken neurons demonstrated some axosomatic synapses as shown in Figure 10. This fact created doubt whether these changes might be real degenerating alterations or not, because the axon terminals seemed intact and the synaptic contacting areas was preserved.

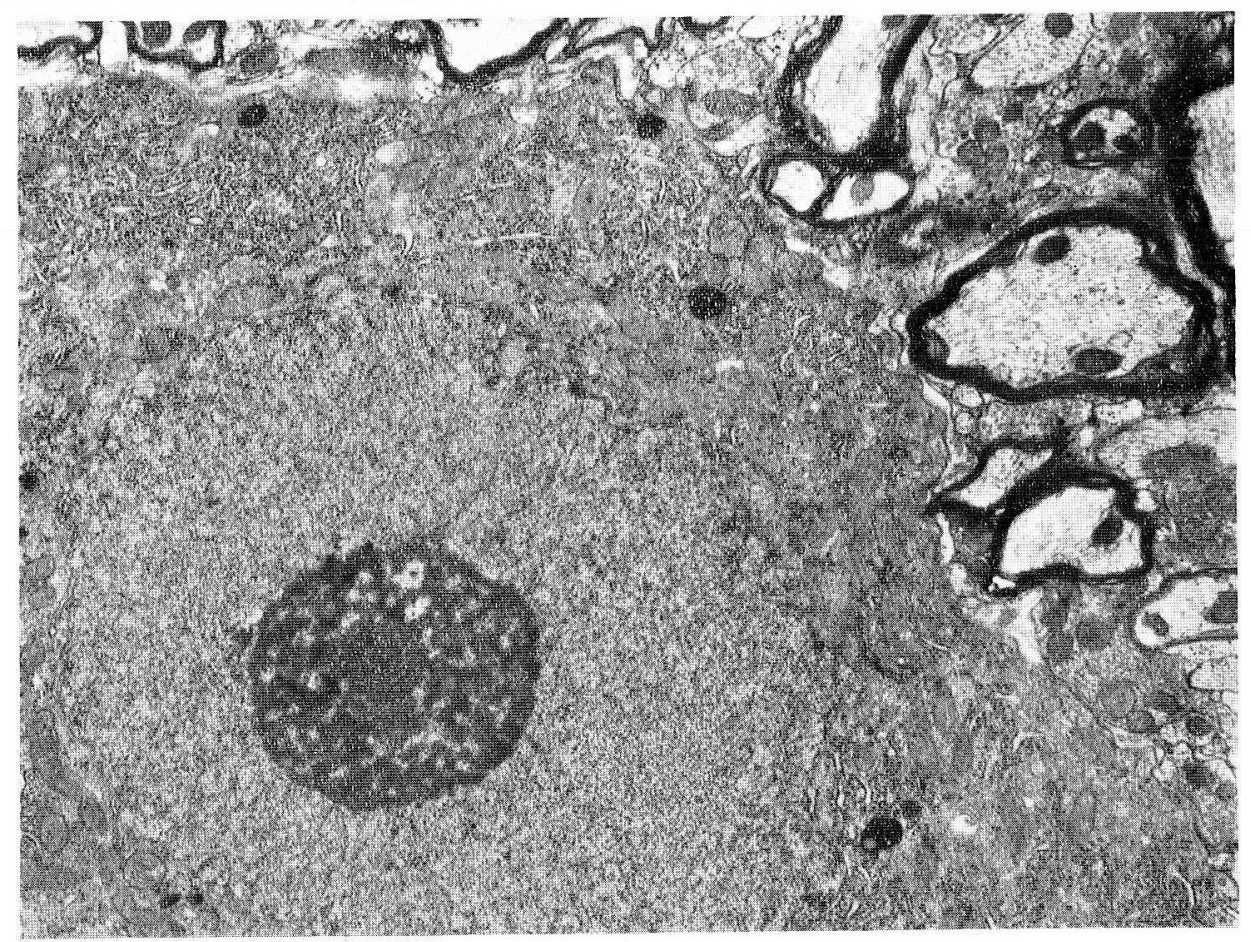

Fig. 7. Degenerating neuron after 10 day survival. Denser matrices both in cytoplasm and nucleoplasm make it diffcult to distinguish sharply the fine structures. The prominent nucleolus, numerous polysomes and free ribosomes are mostly retained though membranous structures in many cell organelles are rather obscure. $\times 8,300$

In the neuropil the segments of the dense dendrites were frequently observed to make synapses with seemingly normal terminals or those containing glycogen (Fig. 11, 12). The dense dendrites were fully packed with neurofilaments, neurotubules, long mitochondria and small amounts of the Nissl substances mainly composed of free ribosomes (Fig. 11, 12). Probably these dense dendrites and the abovementioned dark neurons might coincide with each other. On the control side a small number of dense dendrites were unexpectedly observed, though a dense shrunken neuron was not exactly traced. As a matter of fact, there was much difference in 


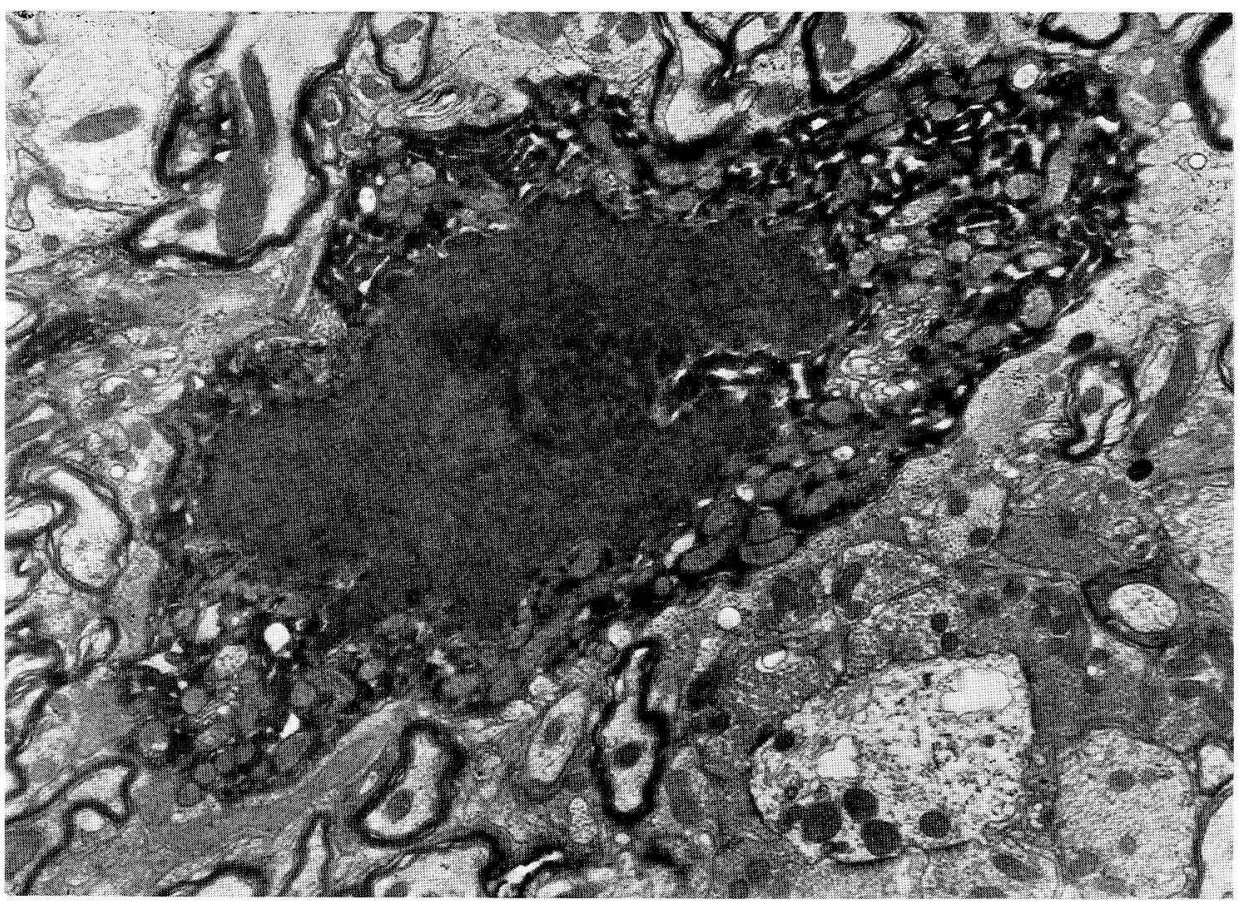

Fig. 8. Dark shrunken neuron after 10 day survival. Astrocytal end feet with gliofilaments and glycogen particles are enclosing a wide area of the neuronal surface. $\times 7,400$

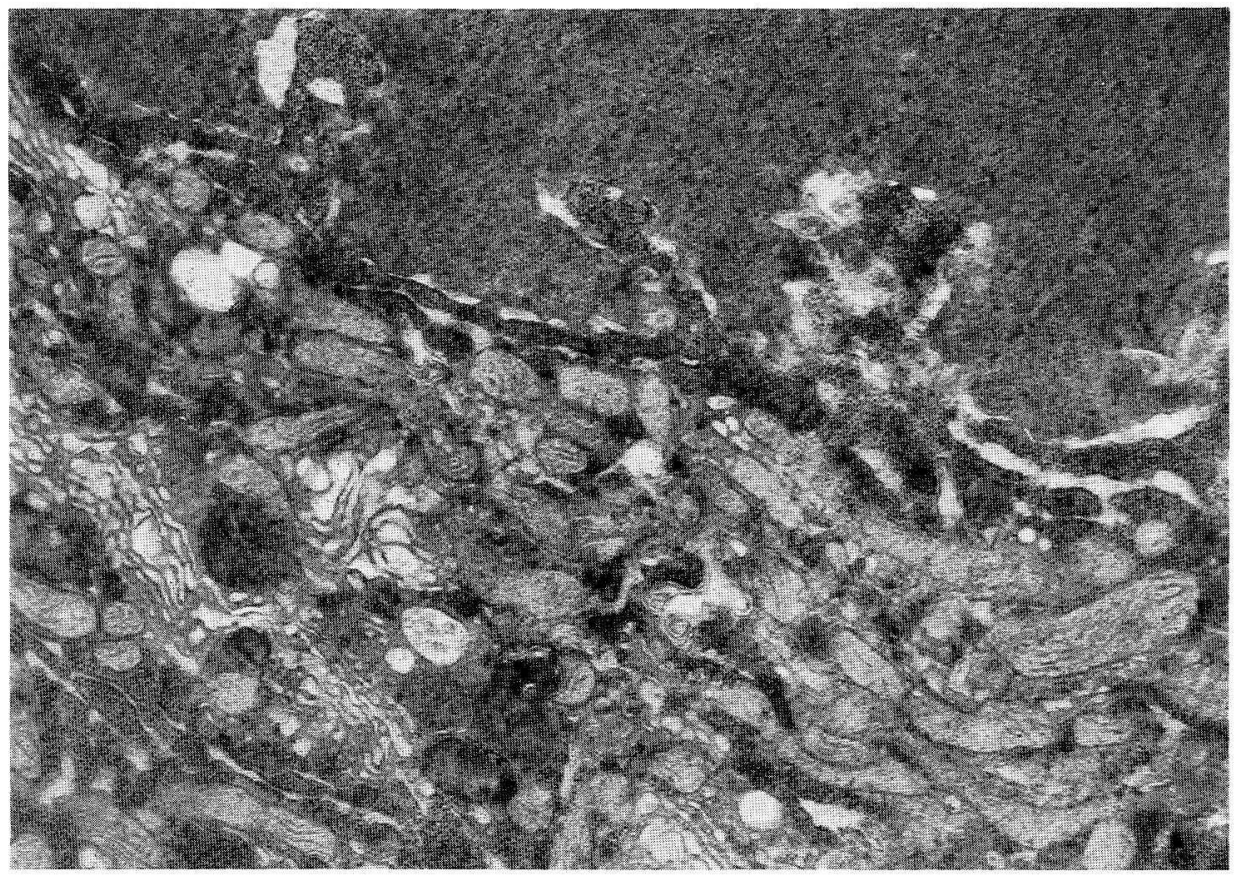

Fig. 9. Higher magnification of the dark shrunken neuron after 10 day survival. The space between the nuclear membranes increases in width up to $2,000 \AA$ except for the nuclear pore area. The cisterns of the Golgi apparatus and the granular endoplasmic reticulum are spreading. $\times 18,000$ 


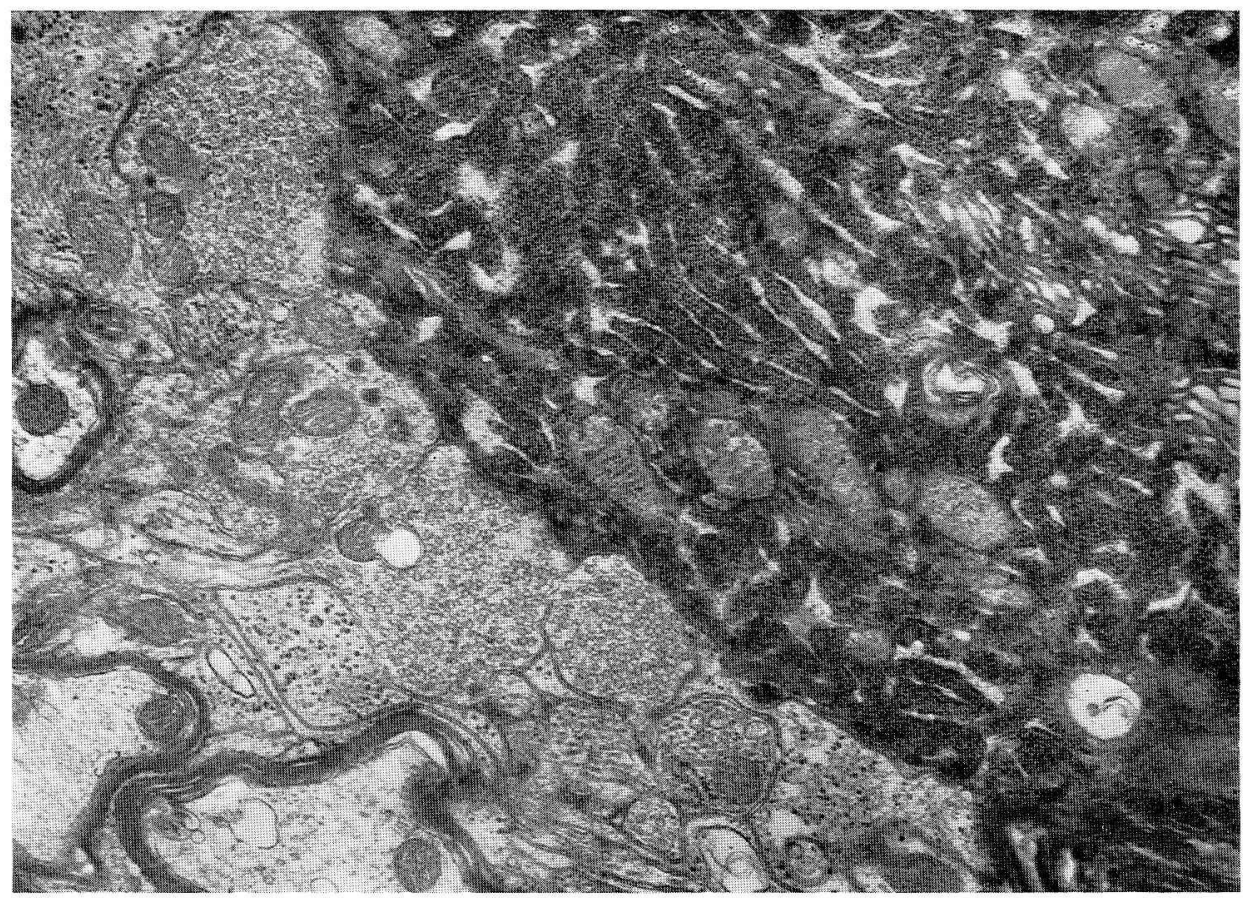

Fig. 10. Peripheral area of the dark shrunken neuron after 10 day survival. Synaptic vesicles in the axon terminals contacting with the dense neuron seem to be intact. Glycogen accumulation is observed in astrocytal processes. $\times 18,000$

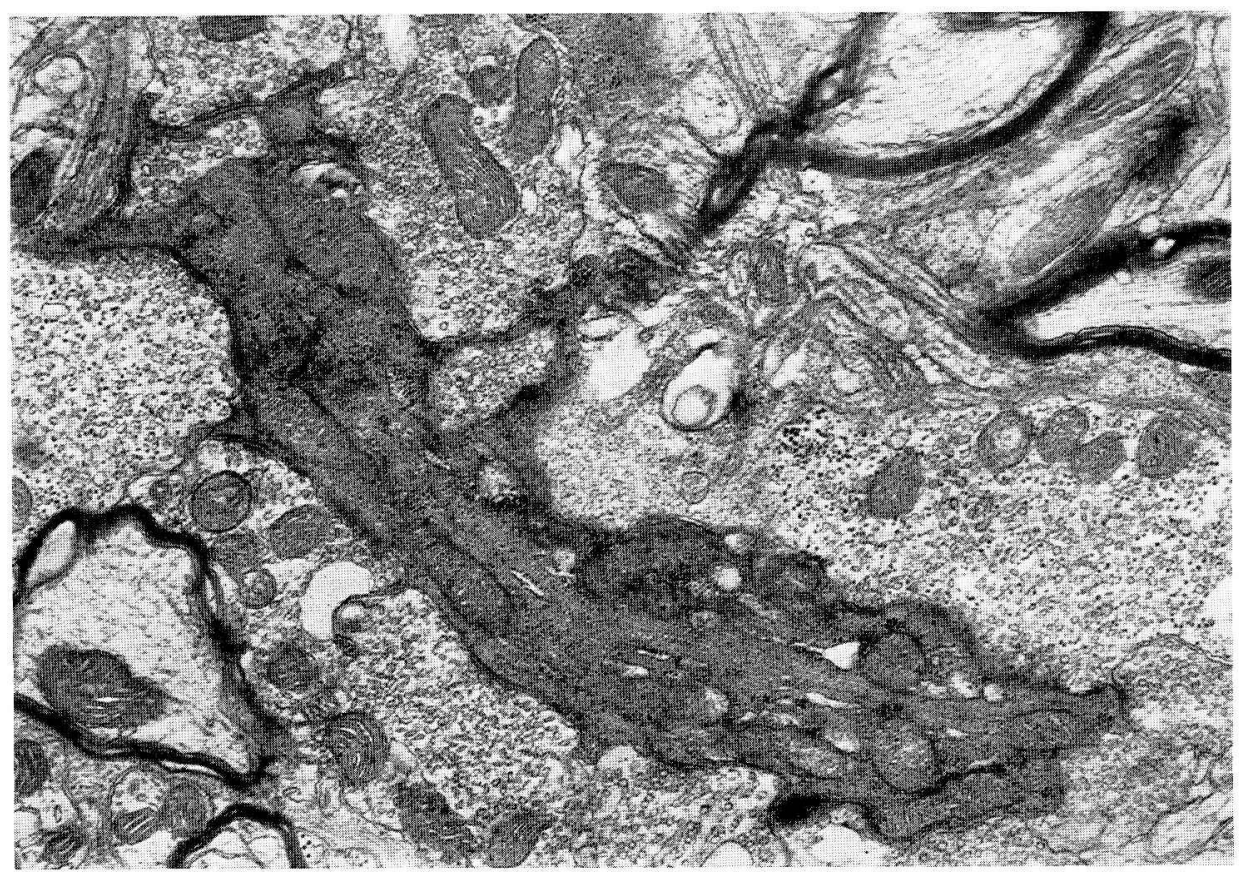

Fig. 11. Dark dendrites making synaptic contacts with several axon terminals after 10 day survival.

The dendrite is loaded with numerous neurotubules, large mitochondria and free dense particles. Two axon terminals containing glycogen particles show the mild changes of synaptic vesicles in size. $\times 18,000$ 
the frequency of appearance of the dense dendrites and neurons between the affected and control sides.

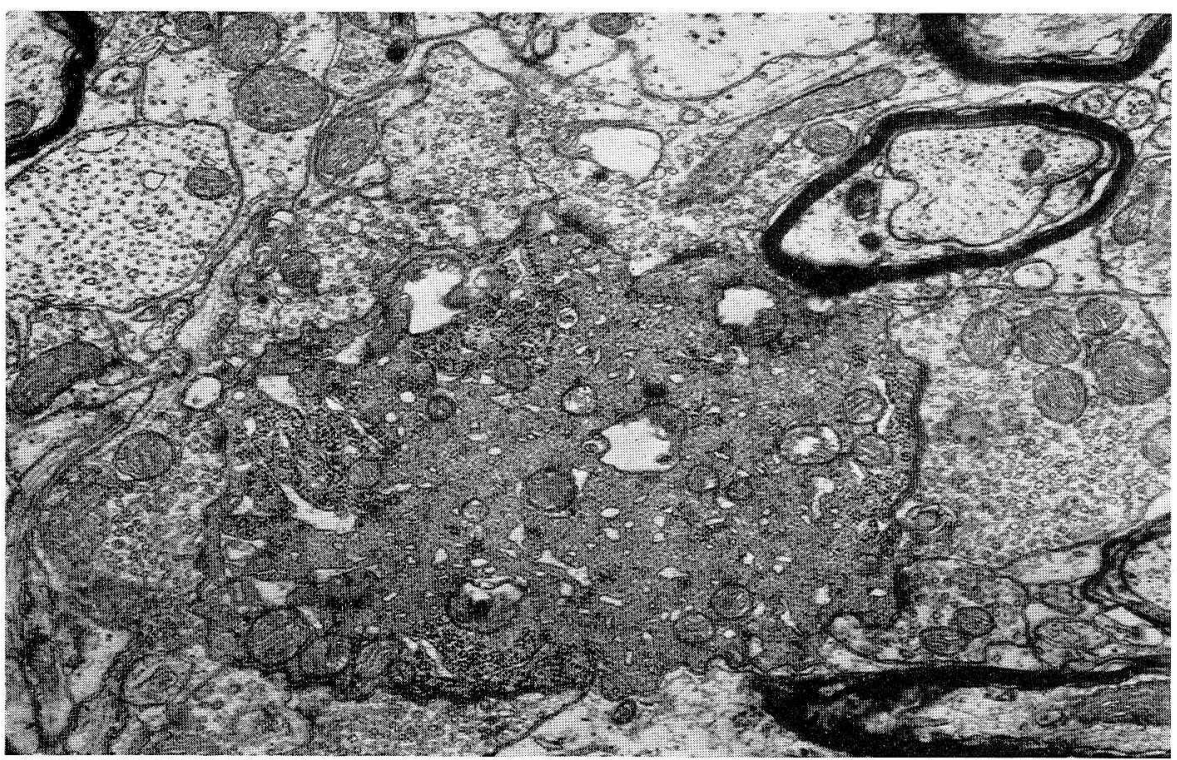

Fig. 12. Cross section of a dark dendrite after 21 day survival. The Nissl substances are limited to the peripheral area, while the central area is occupied with numerous neurotubules and neurofilaments. The axon terminals hardly show any change. $\times 15,800$

\section{Observations in the neuropil of the affected motor nucleus}

In the neuropil of the motor nucleus the degenerating figures similar to those in the mesencephalic nucleus were sometimes observed (Fig. 13, 14). These processes contained small neurofilamentous bundles, lamellated dense bodies, small mitochondria without clear cristae, vesicles or glycogen-like dense particles. These figures might represent some stage in the degenerating process of large neuronal processes. Survival periods of $18 \mathrm{hrs}$ following neurotomy were enough to observe an appearance of the dense axon terminals. The dense terminals sometimes made axo-somatic and axo-dendritic synapses (Fig. 15, 16). The synaptic vesicles in such dense terminals seemed almost always to be normal in size, number and shape. Another conspicuous change was the accumulation of glycogen particles, which were not limited in the dense terminals but in several light terminals (Fig. 11, 16). Small neurofilamentous deposits were also revealed in a few terminals being both dense and light (Fig. 14, 15). After 7 days, changes such as glycogen deposit and an increase in electron density of the axoplasm in the myelinated fibers and sometimes accumulation of dense bodies were recognized in the neuropil of the affected motor nucleus.

As reported in the mesencephalic nucleus (Iмамото, 1972b), the activation of the pericytes occurred also in the motor nucleus after 17 hrs (Fig. $20 \mathrm{~A}, \mathrm{~B}$ ). The cytoplasmic matrix in the pericytes became dense, and amorphous dense material, inclusion bodies and autophagic vacuoles apparently increased in the cytoplasm (Fig. 20A, B). The loosening of the basement membrane was followed by the appearance of 


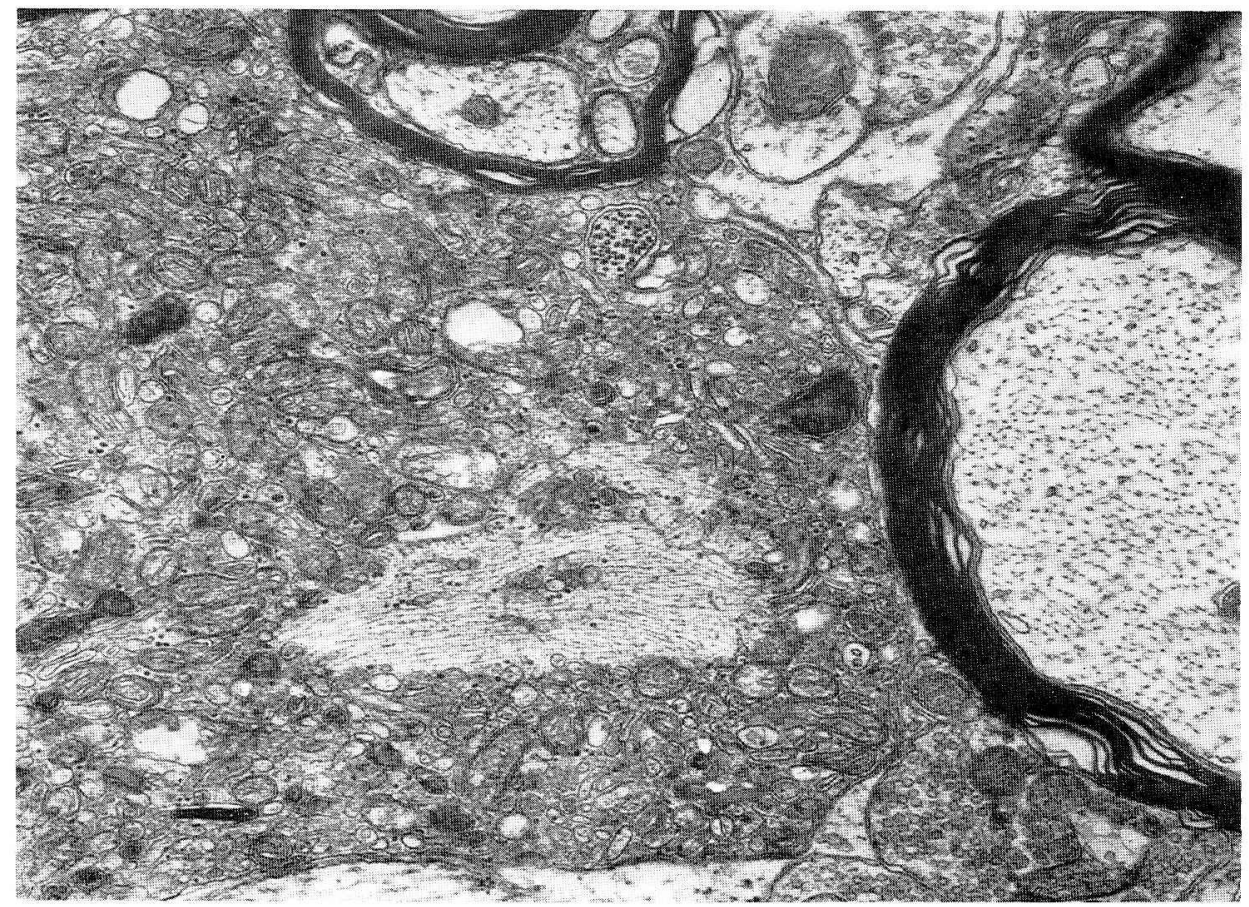

Fig. 13. Degenerating axon hillock area after 21 day survival. Abnormal dense matrix contains numerous mitochondria varying in size, neurofilaments, many vesicles being empty or dense cored and glycogen-like particles. $\times 20,700$

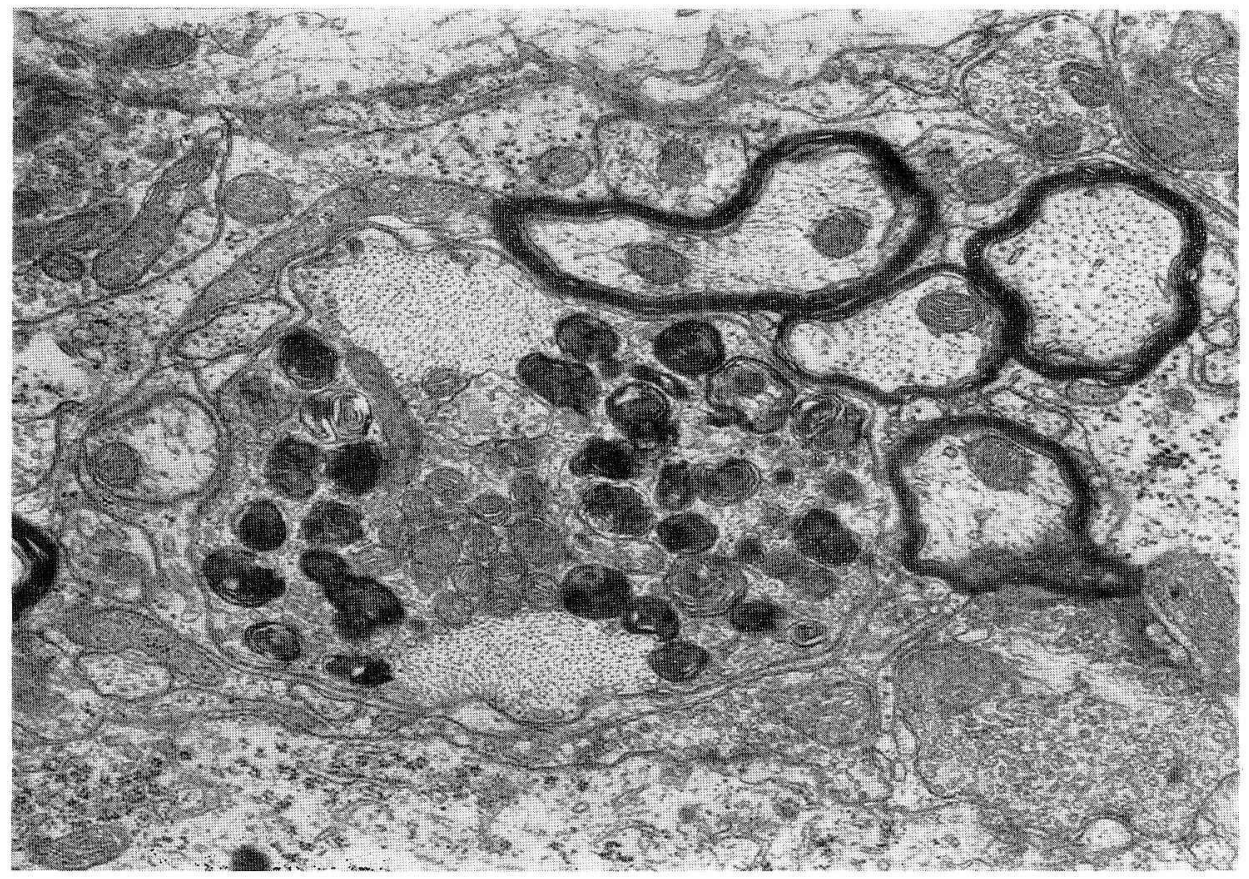

Fig. 14. Degenerating process after 21 day survival. Numerous lamellated dense bodies, small mitochondria and two neurofilamentous areas are observed. $\quad \times 18,000$ 


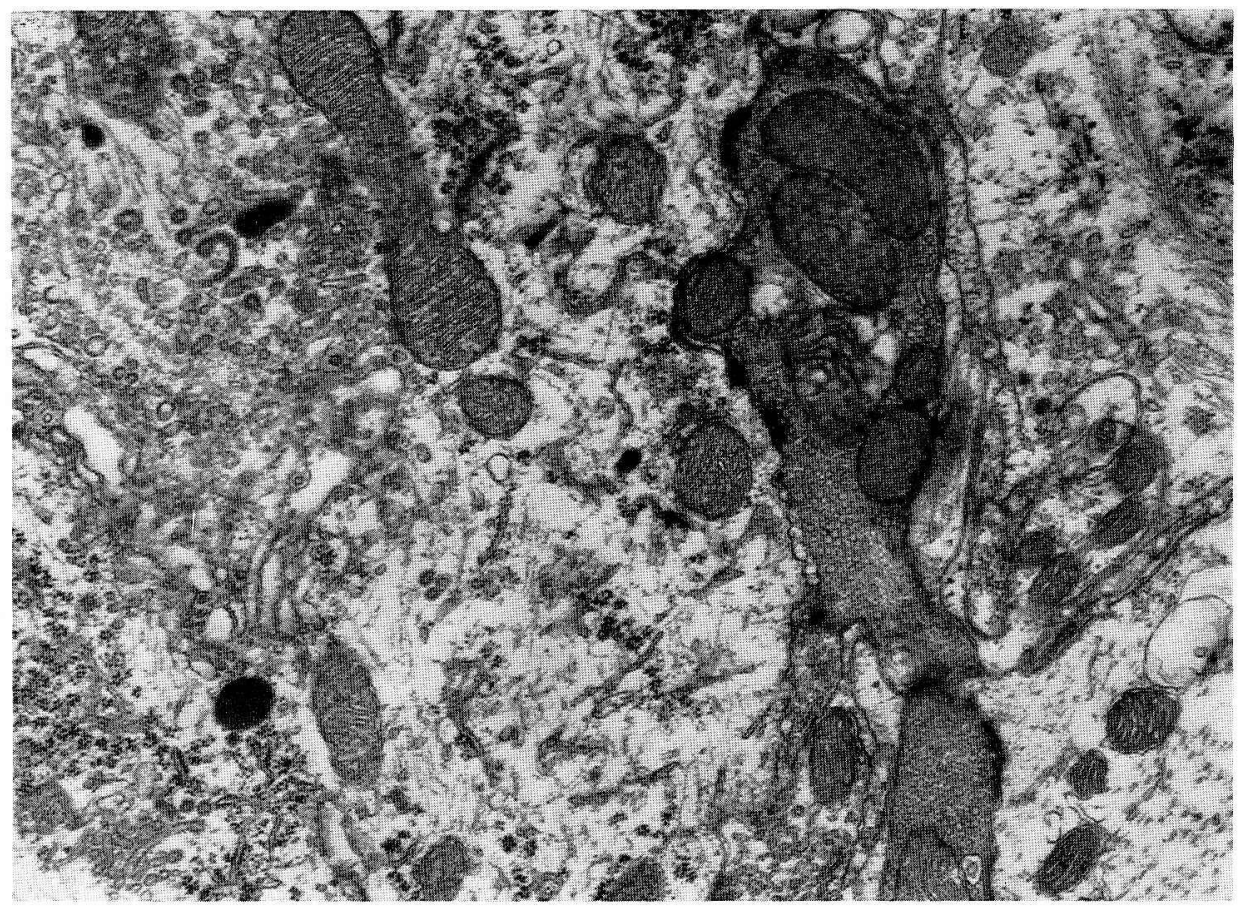

Fig. 15. Dark axon terminal contacting with the trigeminal motor neuron after 2 day survival. Dense mitochondria with few cristae and small amounts of neurofilaments are observed among synaptic vesicles of ordinary size. In the neuron there are well-developed Golgi vesicular structures. $\times 18,900$

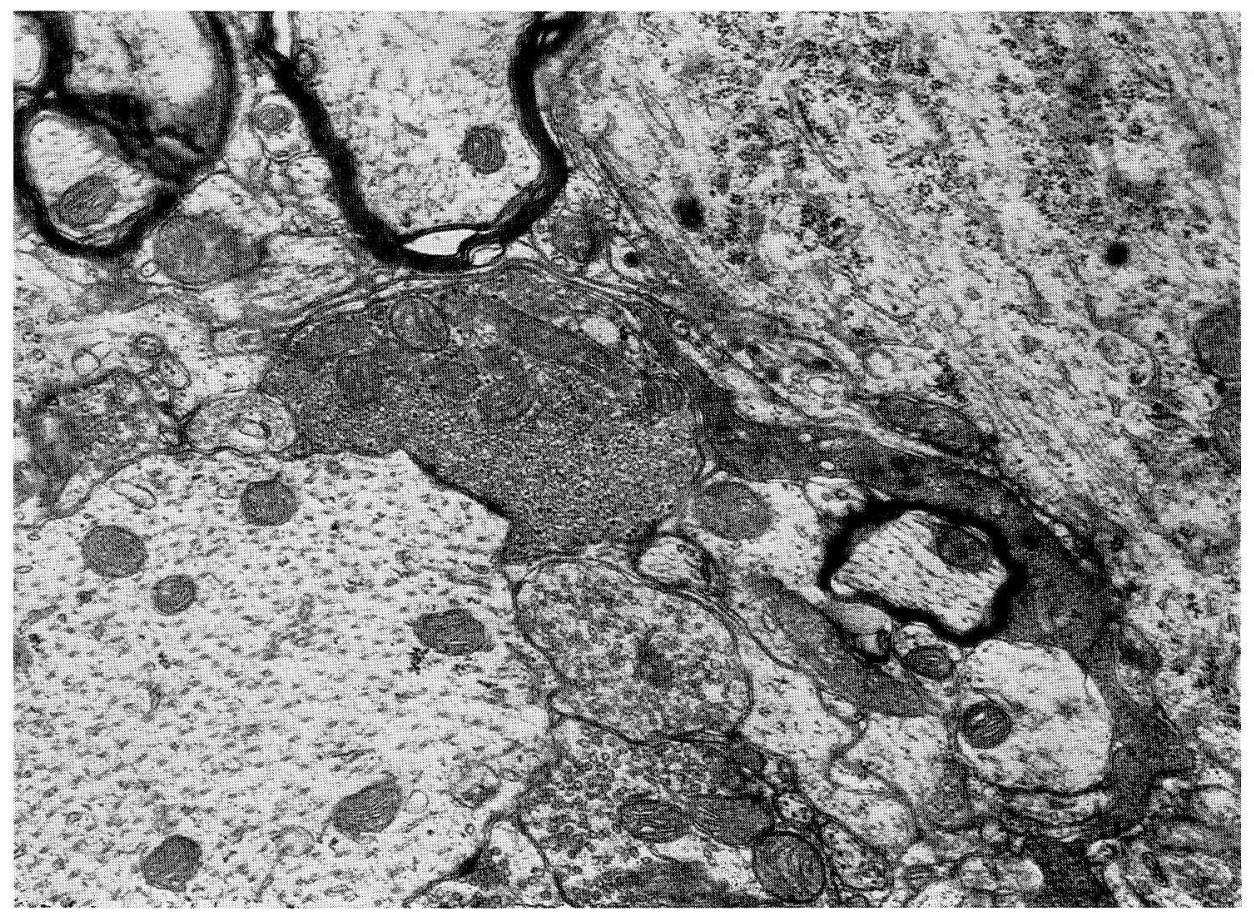

Fig. 16. 
micropinocytotic vesicles along the membrane (Fig. 20B). These changes corresponded to the histochemical data that the vascular area showed increased activities of glucose-6-phosphate dehydrogenase (G6PDH) and acid phosphatase (ACP) (IмAмото, 1972a).
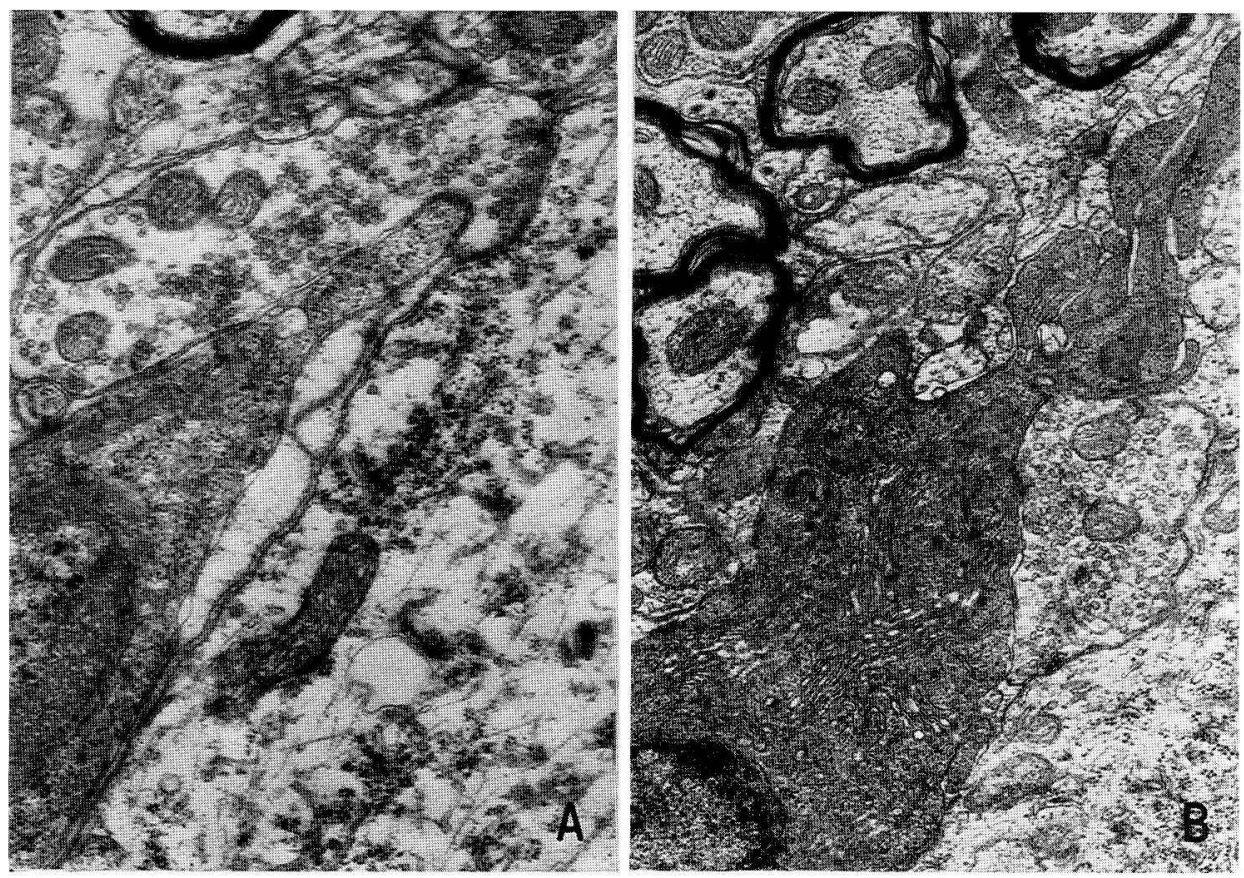

Fig. 17. Activated microglial cells migrating along the motor neurons. The microglial process seems to release an intact axon terminal from the surface of the motor neuron (A). Satellitic micro-

glia show well-developed cytoplasm with many finger-like branching processes $(\mathbf{B}) . \quad \times 18,000$

There were marked glial reaction during retrograde degeneration. Particularly the glial proliferation as satellites was severe till 2 days after neurotomy, even if most of the neurons showed no serious change in the early periods. The affected neurons often became covered by more than 5 or 6 glial cells (Fig. 5). It was interesting that the glial proliferation prominently occurred within a short time. Although the glial cell had a small and elongated nucleus with dense chromatin along the nuclear rim resembling the microglial one, the cytoplasm was quite different from the ordinary microglial cytoplasm (Fig. 17B, 18). The granular endoplasmic reticulum, the Golgi apparatus and dense bodies were well developed in the dense hypertrophied perikaryon, and such satellites often had many finger-like processes (Fig. 17B). Several glial cells might always migrate around an affected neuron without adhesion to one place of neuronal surface, separating some intact terminals from the synaptic area by the infiltration of the finger-like processes (Fig. 17A). At the end of phagocytosis of a necrotic neuron, only one glial cell enclosed it with enormously developed cytoplasm

Fig. 16. Dark axon terminal contacting with a normal dendrite after 7 day survival. The terminal shows glycogen dispersion among spherical and flat vesicles. Note the infiltration of dense finger-like processes of the activated microglia near the dense terminal. $\times 20,700$ 


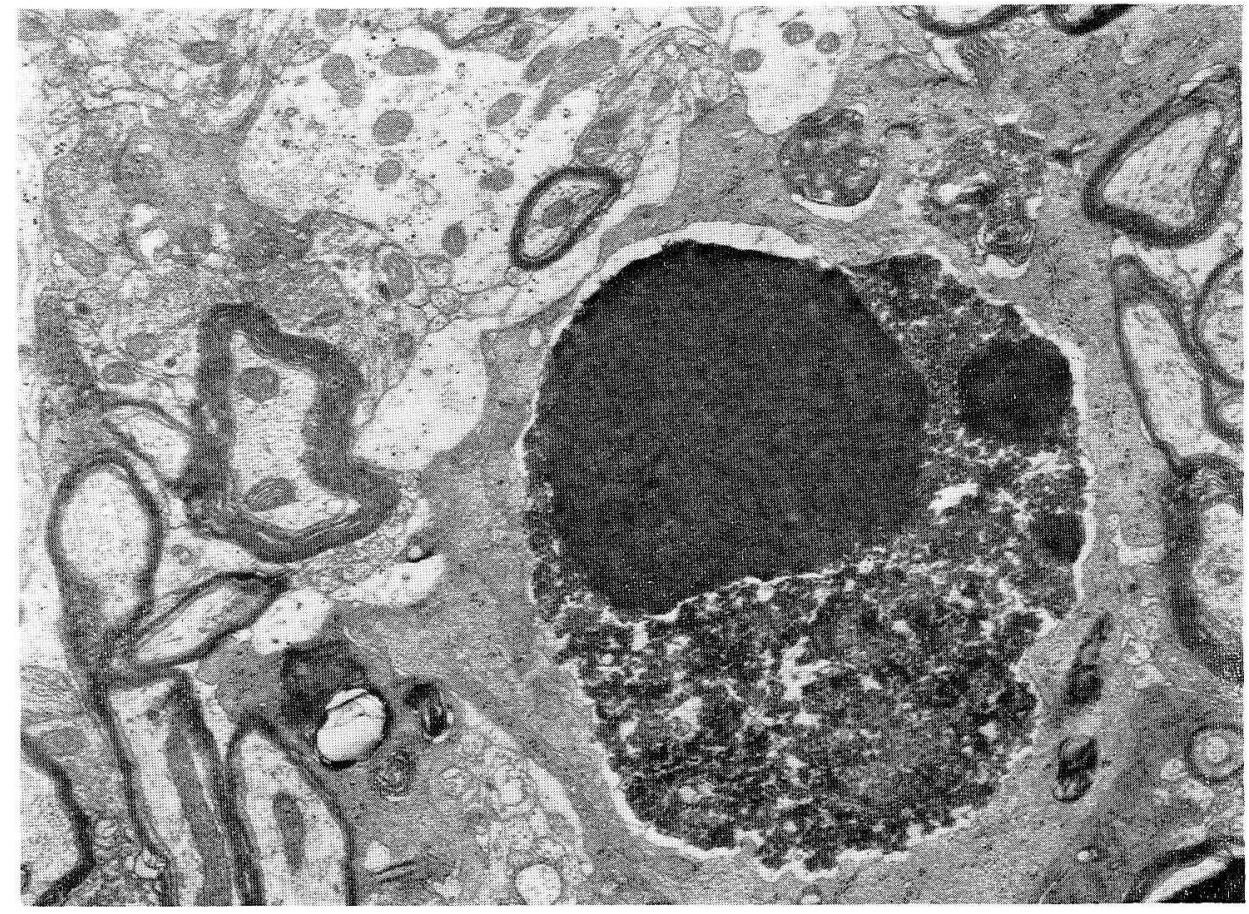

Fig. 18. Microglial phagocytosis after 10 day survival. The well-developed microglial cytoplasm is enclosing a necrotic neuron which is composed of a nuclear-like dense mass and sponge-like cytoplasmic material. $\times 13,500$

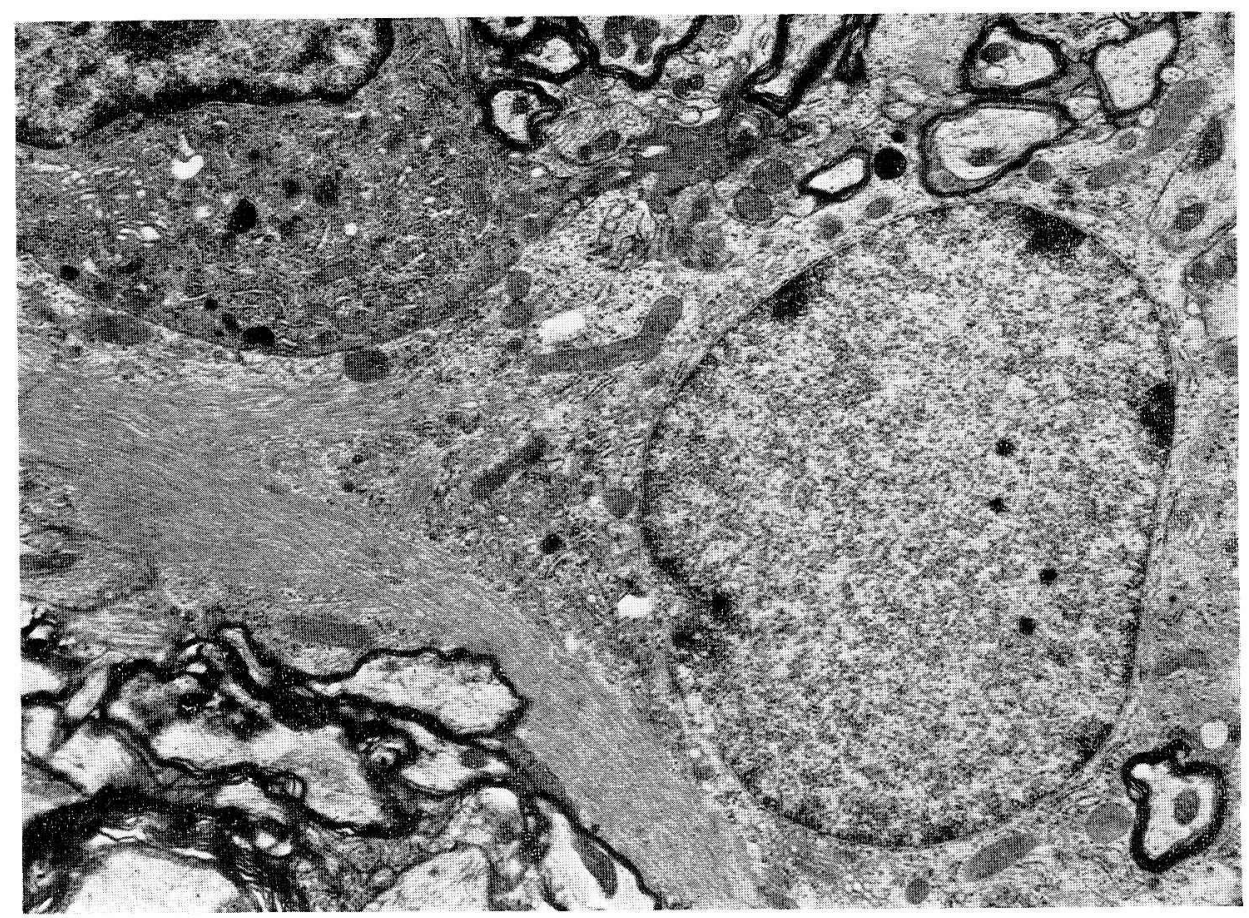

Fig. 19. 

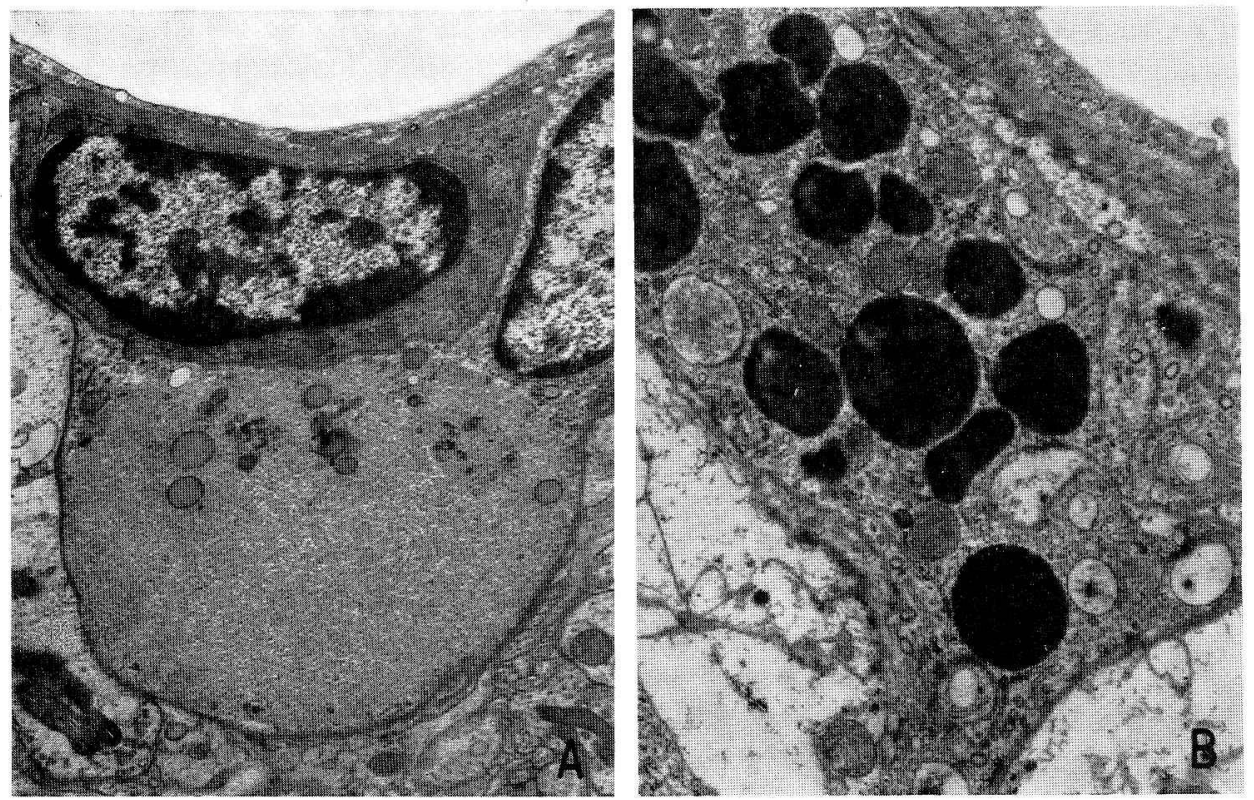

Fig. 20. Activated pericytes covered by basement membranes. A. after 18 hr survival, $\times 9,000$ B. 7 day survival, $\times 10,800$ The activated pericytes contain large amounts of amorphous substances, dense bodies, autophagic vacuoles, coated vesicles and pinocytotic vesicles.

as shown in figure 18. These cells should be regarded as activated microglial cells. In the meanwhile the astrocytal reaction was initially characterized by the glycogen accumulation from 18 hrs after neurotomy, especialy in vascular and perineuronal areas (Fig. 2B, 6). Subsequently, gliofilamentous aggregation occurred not only in the peripheral end feet but also in the perikaryal area (Fig. 19). An increase in the number of astrocytes was not ascertained in spite of the astrocytal swelling in the affected neuropil.

\section{Discussion}

The alterations of the Nissl pattern and of its quantity were the initial changes in the terigeminal motor neurons as well as the mesencephalic neurons (Iмамото 1972b). It was reasonable to consider that activated formation of the Nissl substances was the first noticeable change and a unique phenomenon compatible with regeneration (LenTz, 1967). Probably protein synthesis for reorganization or regeneration was activated by polysomes, and the turnover of the cytoplasmc RNA likely became rapid, as suggested by the increased activities of G6PDH and ACP in the affected neurons (Iмамото, 1972a). Though the significance of the change from the parallel array of the long granular endoplasmic reticulum to polysome clusters was still obscure, the author considered that polysomes were concerned with the synthesis of cell structural protein and that granular endoplasmic reticulum were associated with the synthesis

Fig. 19. Reacting astrocyte in the center and oligodendrocyte in the upper left of the figure after 10 day survival. The gliofilamentous aggregation occurs in the hypertrophied astrocytal perikaryon while numeros glycogen accumulations are present in the peripheral processes. $\times 8,100$ 
of proteins reflecting neuronal function (Lieberman, 1971). Not only changes in cell organelles but also an increase in electron density of the cytoplasmic matrix might be concerned with the proliferation of polysomes. Subsequently, alterations from polysome clusters into single ribosomes, a decrease in quantity of ribosomes and the dilatation of cisterns of the granular endoplasmic reticulum revealed to be advanced degenerating phenomenon (BARRon et al., 1967; ToRvik, 1972; Iмамото. 1972b). Mitochondrial abnormality in ultrastructures, such as disappearance of the cristae and lower density in the matrix, corresponded to the reduced SDH activity in the affected neurons (Iмамото, 1972a). However, the number of mitochondria seemed to increase in the axon hillock area (Hudson et al., 1961; PANnESE, 1963).

There were many aspects to be considered about the dense shrunken neurons recognized in the affected motor nucleus. Although CAMMERMEYER (1960) has comfirmed that hyperchromic dark neurons might be due to postmortem artifacts under a light microscope, dark neurons were observed in our well-fixed materials by perfect perfusion particularly in the affected side. It may be unreasonable to consider it as a mere artifact without any physiological meanings, even if the appearance cannot be ascribed to the direct effect of the neurotomy. It is conceivable that the internal biochemical or physicochemical condition of the neuronal cytoplasm under axonal reaction might be suitable for producing strong dehydration during perfusion fixation. As CoHEn and PAPPAs (1969) have reported the possibility of the occurrence of dark neurons under normal conditions, its relation to an affect of neurotomy remained uncertain.

Retrograde degeneration in neuronal perikarya and axons (both motor and sensory) has been represented by an extensive increase of neurofilaments and neurotubules with or without special aggregation (TAKANo, 1965; LAMPART, 1967; ZelenÁ, 1971; Price and Porter, 1972; Torvik, 1972; Imamoto, 1972b). In spite of the marked increase of the Nissl substances, the proliferation of the neurofilaments was rather slight in the trigeminal motor neurons. The fact suggested that the great accumulation of neurofilaments was the last phenomenon of the degenerative change and the affected trigeminal motor neurons might be restored to the normal state easier than the mesencephalic neurons.

The morphological findings as reliable criteria in the degenerating axon terminals were summarized in the following features. 1. An increased electron density of the axoplasm (Mugnaini et al., 1967; McMahan, 1967; Ralston, 1968; Raisman, 1969; WonG-RILEY, 1972), 2. Accumulation of neurofilamentous materials (GRAY and Hamlyn, 1962; Mugnaini and Walberg, 1967; Rogers, 1972), 3. Synaptic vesicle enlargement (CuÉnod et al., 1970; AkerT et al., 1971; KaWANA et al., 1971; Rogers, 1972), 4. Changes in distribution or number of the synaptic vesicles (MugnaINI et al., 1967; Rogers, 1972), 5. Accumulation of glycogen (Konishi et al., 1970). In many cases such initial changes were followed by the darkened shrinkage of the terminals, which were often enclosed by astrocytal end feet (Mugnaini and WALBERG, 1967; McMaHAN, 1967). It was generally said that some axon collaterals from the trigeminal mesencephalic neurons innervate the motor neurons and make mono-synaptic reflex arcs (CAJAL, 1911; Sмiтн et al, 1967). In fact the neuropil of the motor nucleus revealed reduced enzyme activities concerning glucose metabolism (Iмамото, 1972a) and concomitantly abnormal terminals were often observed. In the dark axon terminals there were 
seemingly intact synaptic vesicles with or without glycogen particles and neurofilament deposits. On the other hand, there were glycogen accumulation or neurofilament deposits in the light axon terminals with somewhat enlarged synaptic vesicles. They were supposed to be the axon-collaterals of the affected mesencephalic neurons, but it was difficult to consider that such abnormalities were real degenerating features. In the motor nucleus a darkly shrunken terminal enclosed by astrocytal end feet was not demonstrated in the later periods; furthermore, most of the abnormal terminals were still adhering to the post-synaptic elements. Some of them might be the degenerating terminals of necrotic mesencephalic neurons but others might show the reversible changes following a decrease in neuronal function. Some investigators emphasized that the dense axon terminals were a special type of the normal boutons, and that a careful review of the validity of the criteria was necessary (IBATA and Otsuka, 1968; Cohen and Pappas, 1969). To consider the dense axon terminals as well as dense dendrites or dense shrunken neurons as the real degenerating structures perhaps needs more discussion, though GRANT and Westman (1968) have reported that the degenerating dendrites were shrunken and electron dense, and surrounded by boutons during axonal transection.

It was a very interesting phenomenon that the glial cells were activated without a direct destruction of the brain. Recent light microscopic and autoradiographic studies have exhibited extensive glial proliferation as satellites, which were identified as microglial cells (Watson, 1965; Suöstrand, 1965; 1971; KreutzBerG, 1966; Blinzinger and KREUTZBERG, 1968; TorviK, 1971). The microglia have the most important role in phagocytosis of the degenerating materials (CoNRADI, 1969; ToRviK and SkJörten, 1971b; ToRviK, 1972; Wong-RILEy, 1972), though astrocytes and oligodendrocytes are also considered to have a role in removal of degenerating synaptic terminals or myelinated axons (McMahn, 1967; Mugnaini et al., 1967; RAISMAN, 1969). Actually the process of the removal of degenerating axon terminals might occur more quickly than the removal of the necrotic neurons. However, the significance of microglial satellites in the early period of the axonal reaction and the origin of activated microglia should be traced more intensely in the future. As reported by BLINZINGER and KREUTZBERG (1968), the author observed the microglial finger-like processes which seemingly release intact terminals from the post-synaptic side, and subsequently infiltration of astrocytal end feet with glycogen particles occurred in the area.

Astrocytal reaction during experimental brain injury has been given much attention by many investigators. It is commonly characterized by glycogen accumulation, gliofilamentous proliferation and cytoplasmic swelling (MiQUEL and HAYMAKER, 1965; KIRKPATRICK, 1968; TORVIK and SkJÖRTEN, 1971b). However, astrocytal proliferation was not exactly demonstrated. Whether the astrocytal reaction is a passive change or an active one has not been clarified. Many possibilities were considered on the basis of the glycogen accumulation in the axon terminals and astrocytal processes, and reduced enzyme activities of $\mathrm{SDH}, \mathrm{LDH}$ and $\mathrm{ALD}$ in the neuropil of the trigeminal motor nucleus (Імамото, 1972a). The changes were probably caused by the disturbance of glucose transport and its metabolism in the astrocyte-neuron unit, suggesting a decreased energy requirement in the synaptic area or an increased glucose permeability through the blood brain barrier or lower glucose uptake by the affected neurons. 
Acknowledgement. The author wishes to thank Prof. N. SHImizu for his helpful advice and critical reading of this manuscript.

\section{三叉神経第 3 枝切断後の運動核における微細構造の変化}

$$
\text { 今 本 喜久子 }
$$

ラットの三叉神経第 3 枝切断に伴なう逆行性変性の微細構造它 その運動核において, 術後17時間から95日にわたって観察した．正常時に長い粗面小胞体の層板状配列で形成 される典型的虎斑状のニッスル物質は，術後次第にその配列を乱し短小となる. それに付 随して，核陷凹部と細胞辺縁部は ポリゾームの増加が著明となる. 変性壊死に向から細 胞では粗面小胞体の槽が拡大し，ポリゾームの集塊は単一遊離リボゾームとなり減少す る.乙かし 全般的に運動核細胞の壊死像は少なく，その多くは回復するものと考える。 細胞内小器官ではよく発達したゴルジ装置は層板状のゴルジ槽を主とするものから，ゴ ルジ小胞，包衣小胞，デンス体等の小胞構造を主とするものへと变化した. 神経細線維 や神経細管は増加するが，集束をなさず散在する。ミトコンドリアはクリスタが不明瞭 となり基質の電子密度は低下する。ニューロピルでは 中脳路核細胞の軸索側副枝と考え られる終末に軸索基質の高電子密度のもの，神経細線維含有のもの，グリコゲン含有の もの等の異常を観察した．神経切断と同時に小膠細胞ほ随伴細胞として増殖し，術後 2 日目にほほとんどの細胞ほ数個の小膠細胞で包囲される.これらの随伴細胞は指状突起 をもら，細胞表面でシナプスをつくる終末を分離するように遊走する. 壊死細胞は活性 化した小膠細胞の肥大細胞質で囲まれ，食作用を受ける. 神経細胞や血管周囲の星状膠 細胞の突起には術後早期からグリコゲンが蓄積し，その核周囲にグリオフィラメントの 増加が目立ち，胞体は肥大するが数の変化は認めがたかった。

\section{References}

Akert, K., M. Cuénod, and H. Moor: Further observations on the enlargement of synaptic vesicles in degenerating optic nerve terminals. Brain Res. 25: 255-263 (1971).

Barron, K. D., P. F. Doolin and J. B. Oldershaw: Ultrastructural observations on retrograde atrophy of lateral geniculate body. 1. Neuronal alterations. J. Neuropathol. exp. Neurol. 26: 300-326 (1967).

Blinzinger, K. and G. Kreutzberg: Displacement of synaptic terminals from regenerating motoneurons by microglial cells. Z. Zellforsch. 85: 145-157 (1968).

Cajal, S. R.: Histologie du système nerveux. T. 1 et 2, Paris, A. Maloine. (1909-1911).

Cammermeyer, J.: The post-mortem origin and mechanism of neuronal hyperchromatosis and nuclear pyknosis. Exp. Neurol. 2: 379-405 (1960).

Cohen, E. B. and G. D. Pappas: Dark profiles in the apparently normal central nervous system. A problem in the electron microscopic identification of early anterograde axonal degeneration. J. comp. Neurol. 136: 375-396 (1969).

Conradi, S.: Ultrastructure of dorsal root boutons on lumbosacral motoneurons of the adult cat, as revealed by dorsal root section. Acta physiol. scand., suppl. 332: 85-115 (1969).

Cuénod, M., C. Sandri and K. Akert: Enlarged synaptic vesicles as early sign of secondary degeneration in the optic nerve terminals of the pigeon. J. Cell Sci. 6: 605-613 (1970). 
Grant, G. and J. Westman: Degenerative changes in dendrites central to axonal transection. Experientia 24: 169-170 (1968).

Gray, E. G. and L. H. Hamlyn: Electron microscopy of experimental degeneration in the avian optic tectum. J. Anat. (Lond) 96: 309-316 (1962).

Hudson, G., A. Lazarow and J. E. Hartmann: A quantitative electron microscopic study of mitochondria in motor neurons following axonal section. Exp. Cell Res. 24: 440-456 (1961).

Ibata, Y. and N. Otsuka: Fine structure of synapses in the hippocampus of the rabbit with special reference to dark presynaptic endings. Z. Zellforsch. 91: 547-553 (1968).

Imamoto, K.: Histochemical changes in the mesencephalic nucleus and motor nucleus following neurotomy of the third division of the trigeminal nerve. Arch. histol. jap. 34: 19-33 (1972a).

- Electron microscopic observations in the trigeminal mesencephalic nucleus following neurotomy of the third division of the trigeminal nerve. Arch. histol. jap. 34: 361-374 (1972b).

Imamoto, K. and N. Shimizu: Fine structure of the mesencephalic nucleus of the trigeminal nerve in the rat. Arch. histol. jap. 32: 51-67 (1970).

Kawana, E., K. Akert and H. Bruppacher: Enlargement of synaptic vesicles as early sign of terminal degeneration in the rat caudate nucleus. J. comp. Neurol. 142: 297-308 (1971).

Kirkpatrick, J. B.: Chromatolysis in the hypoglossal nucleus of the rat. An electron microscopic analysis. J. comp. Neurol. 132: 189-212 (1968).

Konishi, A., Y. Nakamura, S. Deura and M. Okamoto: Synaptic degeneration in the central nervous system with special reference to the cat cerebellar afferents. An electron microscopic study (in Japanese). Advances Neurol. Sci. 13: 736-751 (1970).

Kreutzberg, G. W.: Autoradiographische Untersuchung über die Beteiligung von Gliazellen an der axonalen Reaktion im Facialiskern der Ratte. Acta neuropathol. 7: 149-161 (1966).

Lampert, P. W.: A comparative electron microscopic study of reactive, degenerating, and dystrophic axons. J. Neuropathol. exp. Neurol. 26: 345-368 (1967).

Lentz, T. L.: Fine structure of sensory ganglion cells during limb regeneration of the newt triturus. J. comp. Neurol. 131: 301-322 (1967).

Lieberman, A. R.: The axon reaction. A review of the principal features of perikaryal responses to axon injury. Int. Rev. Neurol. 14: 49-124 (1971).

McMahan, U. J.: Fine structure of synapses in the dorsal nucleus of the lateral geniculate body of normal and blinded rats. Z. Zellforsch. 76: 116-146 (1967).

Miquel, J. and W. Haymaker: Astrocytal reactions to ionizing radiation with emphasis on glycogen accumulation. Progress Brain Res. 15: 89-114 (1965).

Mugnaini, E. and F. Walberg: An experimental electron microscopical study on the mode of termination of cerebellar corticovestibular fibers. Exp. Brain Res. 4: 212-236 (1967).

Mugnaini, E., F. Walberg and A. Brodal: Mode of termination of primary vestibular fibers in the lateral vestibular nucleus. An experimental electron microscopical study in the cat. Exp. Brain Res. 4: 187-211 (1967).

Pannese, E, : Investigations on the ultrastructural changes of the spinal ganglion neurons in the course of axon regeneration and cell hypertrophy. Z. Zellforsch. 61: 561-586 (1963).

Price, D. L. and K. R. Porter:The response of ventral horn neurons to axonal transection. J. Cell Biol. 53: 24-37 (1972).

Ralston, H. J.: Dorsal root projections to dorsal horn neurons in the cat spinal cord. J. comp. Neurol. 132: 303-330 (1968).

Raisman, G.: A comparison of the mode of termination of the hippocampal and hypothalamic afferents to the septal nuclei as revealed by electron microscopy of degeneration. Exp. Brain Res. 7: 317-343 (1969).

Rogers, D.: Ultrastructural identification of degenerating boutons of monosynaptic pathways to the lumbosacral segments in cat after spinal hemisection. Exp. Brain Res. 14: 293-311 (1972).

Sjöstrand, J.: Proliferative changes in glial cells during nerve regeneration. Z. Zellforsch. 68: 481-493 (1965). 
Neuroglial proliferation in the hypoglossal nucleus after nerve injury. Exp. Neurol. 30: 178-189 (1971).

Smith, R. D., H. Q. Marcarian and W. T. Niemer: Bilateral relationships of the trigeminal mesencephalic nuclei and mastication. J. comp. Neurol. 131: 79-92 (1967).

Takano, I.: Electron microscopic studies on retrograde chromatolysis in the hypoglossal nucleus and changes in the hypoglossal nerve, following its severance and ligation. Okajimas Fol. anat. jap. 40: 1-69 (1964).

Torvik, A.: Phagocytosis of nerve cells during retrograde degeneration. J. Neuropathol. exp. Neurol. 31: 132-146 (1972).

Torvik, A. and F. Skjörten: Electron microscopic observations on nerve cell regeneration and degeneration after axon lesion. 1. Changes in nerve cell cytoplasm. Acta neuropathol. (Berl) 17: 248-264 (1971a).

after axon lesions. 2. Changes in glial cells. Acta neuropath. (Berl) 17: 265-282 (1971b).

Watson, W. E.: An autoradiographic study of the incorporation of nucleic acid precursors by neurons and glia during nerve regeneration. J. Physiol. (Lond) 180: 741-753 (1965).

Wong-Riley, M. T. T.: Terminal degeneration and glial reactions in the lateral geniculate nucleus of the squirrel monkey after eye removal. J. comp. Neurol. 144: 61-92 (1972).

Zelená, J.: Neurofilaments and microtubules in sensory neurons after peripheral nerve section. $Z$. Zellforsch. 117: 191-211 (1971).

\author{
今本喜久子 \\ 于530 大阪市北区常安町 33 \\ 大阪大学医学部高次神経研究施設 \\ 解剖病理部門
}

Miss Kikuko Iмамото

Department of Neuroanatomy

Institute of Higher Nervous Activity

Osaka University Medical School

33 Joancho, Kitaku, Osaka, 530 Japan 